\section{A Simple Anaesthetic Apparatus for Small Animals}

J. H. CONNOLLY

From the Department of Microbiology, the Queen's University of Belfast

(RECEIVED FOR PUBLICATION DECEMBER 21, 1957)

This apparatus was developed for the anaesthesia of small animals, including infant and adult mice, rats, guinea-pigs, rabbits, and rhesus monkeys.

The general layout of the apparatus is shown in the diagram.

The apparatus consists of an electric pump which drives air through a two-way tap connected to two tubes in an ether container. One of the tubes reaches well below the surface of the ether, and the other ends above the surface. By a turn of the tap it is possible to blow air through the liquid ether or over its surface, giving a higher or lower concentration of ether vapour respectively which is then forced onwards through an outflow tube to a face mask. Two short pieces of tubing serve as the outflow tube and a filling tube respectively.

The pump used was an aquarium aerator of the vibrator type. Possible sparking from motor brushes was thus avoided and the risk of ether explosion eliminated. The pump has a needle valve which controls the air flow.
Rubber and glass tubing of $3 / 16$ in. internal diameter was used throughout.

For the ether container any wide-necked flask or bottle of $250 \mathrm{ml}$. capacity will serve. A $1 \mathrm{lb}$. honey jar fitted with a rubber bung to take the four pieces of glass tubing was found to be a useful size. The two-way tap is connected to the pump and ether bottle by rubber tubing as shown in the diagram. Several feet of rubber tubing connect the outflow tube to the face mask.

The face mask is a pliable polythene filter funnel 2 in. in diameter. Alternatively a thin polythene bag 9 in. by 7 in. which covers the whole head of the animal may be used.

The apparatus is enclosed in a metal or wooden box 8 in. by 6 in. by 4 in., and the pump wired to an electric plug. For convenience the pump may be fitted with a foot switch, so that the ether vapour may be controlled when the hands are fully occupied.

A small funnel is attached to the filling tube and $50 \mathrm{ml}$. of ether poured in. When the apparatus is in use the filling tube is closed by a short piece of rubber tubing and a clip. To induce anaesthesia, the flow valve is opened to give maximum flow, and the two-way tap turned so that air is bubbling through the ether. When the animal is anaesthetized the flow is reduced and the two-way tap turned so that air is now flowing over the surface of the ether. In this manner smooth anaesthesia may be safely maintained for long periods if desired.

For the anaesthesia of mice or rats the outflow tube is placed at the bottom of the jar or box containing the animals.

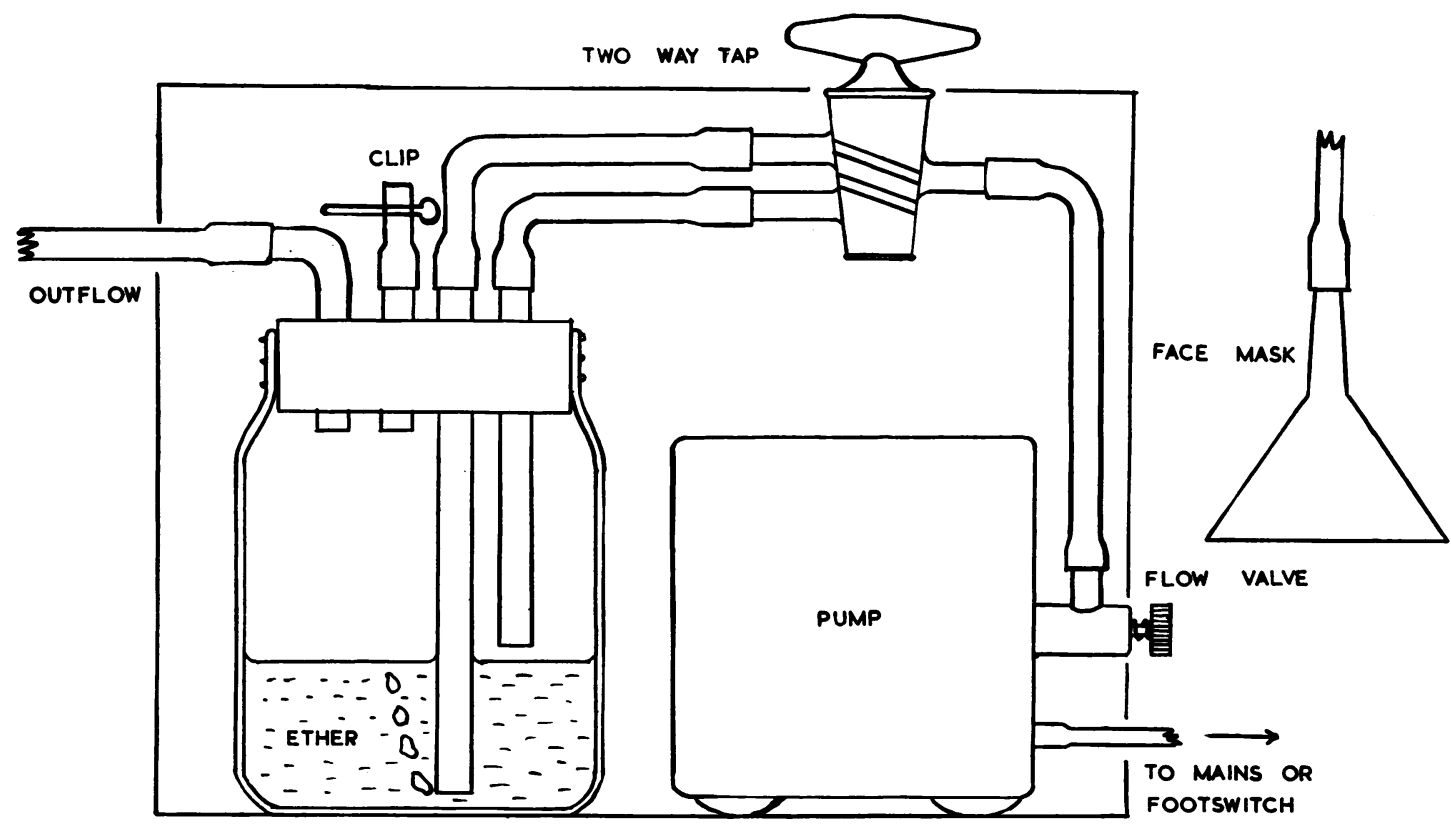


To prevent evaporation of ether when the apparatus is not in use the two-way tap is turned to the neutral position and the outflow tube clipped.

This apparatus is cheap to construct and portable. In contrast to open ether techniques, both vapour flow and ether concentration are controlled, giving smoother anaesthesia and greater safety; also the animal receives the ether vapour and not the operator. There is a considerable saving in ether. since only sufficient is used to induce and maintain anaesthesia and the ether flow is switched off when not required. The apparatus is effective over a wide range of animal sizes, from infant mice up to $8 \mathrm{lb}$. monkeys.

\section{POSTGRADUATE COURSES IN PATHOLOGY ARRANGED BY THE ASSOCIATION OF CLINICAL PATHOLOGISTS, 1958-9}

\begin{tabular}{|c|c|c|c|}
\hline Date & Subject & Institution & For further particulars apply to:- \\
\hline $\begin{array}{ll}1958 \\
\text { Oct. } \\
31 \& \\
\text { Nov. } 1\end{array}$ & $\begin{array}{l}\text { Pathology of Genito-urinary } \\
\text { Diseases }\end{array}$ & $\begin{array}{l}\text { Institute of Urology, in association with St. } \\
\text { Peter's, St. Paul's, and St. Philip's Hospitals }\end{array}$ & $\begin{array}{l}\text { Dr. Roger Pugh, Institute of Urology, } 10 . \\
\text { Henrietta Street, Covent Garden, London. } \\
\text { W.C.1 }\end{array}$ \\
\hline Nov. $21 \& 22$ & $\begin{array}{l}\text { Pathology of Respiratory } \\
\text { Diseases }\end{array}$ & $\begin{array}{l}\text { Institute of Diseases of the Chest and } \\
\text { Brompton Hospital }\end{array}$ & $\begin{array}{l}\text { Dr. J. W. Clegg, Brompton Hospital, London. } \\
\text { S.W.3 }\end{array}$ \\
\hline Nov. $28 \& 29$ & $\begin{array}{l}\text { The Bacteriology of Intestinal } \\
\text { Infections }\end{array}$ & Public Health Laboratory, Colindale & $\begin{array}{l}\text { The Director, Public Health Laboratory, } \\
\text { Colindale Avenue, London, N.W.9 }\end{array}$ \\
\hline Dec. 5 & Diseases of the Heart & Institute of Cardiology & $\begin{array}{l}\text { Dr. R. E. B. Hudson, National Heart Hospital, } \\
\text { Westmoreland Street, W.1 }\end{array}$ \\
\hline Dec. $13 \& 14$ & $\begin{array}{l}\text { Pathology of Diseases of the } \\
\text { Rectum and Colon }\end{array}$ & St. Mark`s Hospital & $\begin{array}{l}\text { Dr. Basil Morson, St. Mark's Hospital, City } \\
\text { Road, London, E.C.1 }\end{array}$ \\
\hline $\begin{array}{c}1959 \\
\text { Jan. } \quad 9 \& 10\end{array}$ & $\begin{array}{l}\text { Pathology of Diseases of } \\
\text { Children }\end{array}$ & $\begin{array}{l}\text { Institute of Child Health and Hcspital for } \\
\text { Sick Children }\end{array}$ & $\begin{array}{l}\text { Dr. Martin Bodian, The Hospital for Sick } \\
\text { Children, Gt. Ormond Street, W.C.1 }\end{array}$ \\
\hline Jan. $16 \& 17$ & $\begin{array}{l}\text { Obstetrical and Gynaecologi- } \\
\text { cal Pathology and "Difficult } \\
\text { Tumours" }\end{array}$ & $\begin{array}{l}\text { Institute of Obstetrics and Gynaecology in } \\
\text { association with the Chelsea Hospital for } \\
\text { Women and the Royal Marsden Hospital }\end{array}$ & $\begin{array}{l}\text { Dr. Magnus Haines, Institute of Obstetrics and } \\
\text { Gynaecology, The Chelsea Hospital for Women, } \\
\text { Dovehouse Street, S.W.3 }\end{array}$ \\
\hline$\overline{\text { Jan. } 23 \& 24}$ & $\begin{array}{l}\text { Pathology of Diseases of } \\
\text { Bones and Joints }\end{array}$ & $\begin{array}{l}\text { Institute of Orthopaedics and Royal } \\
\text { National Orthopaedic Hospital }\end{array}$ & $\begin{array}{l}\text { The Dean, Institute of Orthopaedics, Royal } \\
\text { National Orthopaedic Hospital, 234, Great } \\
\text { Portland Street, W.1 }\end{array}$ \\
\hline Jan. $30 \& 31$ & Diseases of the Eye & Institute of Ophthalmology & $\begin{array}{l}\text { Professor Norman Ashton, Institute of } \\
\text { Ophthalmology, Judd Street, W.C.1 }\end{array}$ \\
\hline Feb. $6 \& 7$ & $\begin{array}{l}\text { Pathology of Diseases of the } \\
\text { Skin }\end{array}$ & $\begin{array}{l}\text { Institute of Dermatology and St. John's } \\
\text { Hospital for Diseases of the Skin }\end{array}$ & $\begin{array}{l}\text { Dr. John Oliver, St. John's Hospital for } \\
\text { Diseases of the Skin, Lisle Street, Leicester } \\
\text { Square, London, W.C.2 }\end{array}$ \\
\hline Feb. $13 \& 14$ & Forensic Pathology & $\begin{array}{l}\text { Committee of Forensic Pathology, Associa- } \\
\text { tion of Clinical Pathology }\end{array}$ & $\begin{array}{l}\text { Dr. Francis E. Camps, Department of Forensic } \\
\text { Medicine, The London Hospital, Medical } \\
\text { College, London, E.1 }\end{array}$ \\
\hline Feb. $20 \& 21$ & $\begin{array}{l}\text { Pathology of Diseases of the } \\
\text { Ear, Nose, and Throat }\end{array}$ & Institute of Laryngology and Otology & $\begin{array}{l}\text { Dr. I. Friedmann, Institute of Laryngology and } \\
\text { Otology, } 330332 \text {, Gray's Inn Road, W.C.1 }\end{array}$ \\
\hline Mar. $6 \& 7$ & $\begin{array}{l}\text { Pathology of Diseases of the } \\
\text { Nervous System }\end{array}$ & $\begin{array}{l}\text { Institute of Neurology in association with } \\
\text { the National Hospital, Queen Square, and } \\
\text { the Maida Vale Hospital, London }\end{array}$ & $\begin{array}{l}\text { Dr. John Cumings, The National Hospital for } \\
\text { Nervous Diseases, Queen Square, London, } \\
\text { W.C.1 }\end{array}$ \\
\hline
\end{tabular}

Note: These " week-end" courses in pathology are intended primarily for trained pathologists of consultant or S.H.M.O. status. In exceptional circumstances pathologists of senior registrar grade or other doctors may be accepted, but only if there are vacancies. Since accommodation is limited early application is desirable. A small fee will be charged at each course and this will be payable on registration.

Note that the course on diseases of the heart is for one day only, December 5. The course on January 16 and 17 will be at the Chelsea Hospital for Women on the Friday and at the Royal Marsden Hospital on the Saturday. Dr. N. F. C. Gowing is organizing the symposium on "difficult tumours" on Saturday, January 17, and those who have registered for this course may send slides to Dr. Gowing at the Royal Marsden Hospital, provided they arrive at least one week before the course.

\section{SYMPOSIUM ON HOSPITAL COCCAL INFECTIONS}

The papers on hospital coccal infections which formed a symposium arranged by the Association of Clinical Pathologists and the Medical Research Council Committee on Cross Infection in Hospital have been edited by R. E. O. Williams and R. A. Shooter. The booklet (price 3s. 6d.) may be obtained from the Swan Press Ltd., Eakers Row, Farringdon Road, London, E.C.1. 